\title{
Pertumbuhan dan Produksi Beberapa Varietas Kedelai (Glycine max L. Merrill) pada Aplikasi Kompos Azolla
}

Growth and Production of Several Soybean Varieties (Glycine max L. Merrill) on Applicaton of Azolla compost

\section{Laila Nazirah}

Staf Pengajar Agroekoteknologi Fakultas Pertanian Universitas Malikussaleh

Correspondence authors :lailanazirah@unimal.ac.id

\section{ABSTRACT}

Growth and yield of several soybean varieties (Glycine max L. Merrill) on the provision of organic fertilizer (Azolla pinnata). The aim is to determine the response of growth and yield of various soybean varieties to the provision of Azolla pinnat compost. The ingredients used in this research were soybean varieties of Baluran, Anjasmoro, Red Fan, Azolla pinnata compost, Phonska and Polybag compound fertilizer. The research method uses a randomized block design (RCBD) factorial pattern. Consists of two factors namely the first factor is the type of variety, namely: V1 = Baluran, $V 2=$ Anjasmoro and V3 = Red Fan. The second factor is Azolla pinnata compost treatment, namely: $A O=0 \mathrm{~g} /$ polybag, $A 1=20 \mathrm{~g} /$ polybag, $A 2=40 \mathrm{~g} /$ polybag and $\mathrm{A} 3=60 \mathrm{~g} /$ polybag so that it consists of 12 combinations of experiments, each experiment consisting of 3 replications. Variety treatment gives effect to plant height, number of leaves of trifoliate dry weight of seeds and weight of 100 seeds, the difference of each variety has different responses to the growing environment. Red fan varieties (V3) are able to adapt well compared to varieties of anjasmoro (V2) and baluran (V1) to plant height growth, number of leaves of trifoliate aged 2, 4, 6 and 8 MST, dry seed weight and 100 seeds. Azolla pinnata compost dose $60 \mathrm{~g} /$ polybag can increase plant growth and yield.

Keywords: variety, soybean, organic fertilizers

\begin{abstract}
ABSTRAK
Pertumbuhan dan hasil beberapa varietas kedelai (Glycine max L. Merrill) terhadap pemberian pupuk organik (Azolla pinnata). Tujuan untuk mengetahui respon pertumbuhan dan hasil berbagai varietas kedelai terhadap pemberian pupuk kompos Azolla pinnat. Bahan yang digunakan dalam penelitian ini adalah benih kedelai varietas Baluran, Anjasmoro, Kipas Merah, kompos Azolla pinnata, pupuk majemuk Phonska dan Polybag. Metode Penelitian menggunakan rancangan acak kelompok (RAK) pola faktorial. Terdiri dari dua faktor yaitu Faktor pertama adalah jenis varietas, yaitu $: \mathrm{V}_{1}=$ Baluran, $\mathrm{V}_{2}=$ Anjasmoro dan $\mathrm{V}_{3}=$ Kipas Merah. Faktor kedua adalah perlakuan kompos Azolla pinnata, yaitu : $\mathrm{A}_{0}=0 \mathrm{~g} /$ polybag, $\mathrm{A}_{1}=20 \mathrm{~g} /$ polybag, $\mathrm{A}_{2}=40 \mathrm{~g} /$ polybag dan $\mathrm{A}_{3}=60 \mathrm{~g} /$ polybag sehingga terdiri dari 12 kombinasi percobaan, masing-masing percobaan terdiri dari 3 ulangan. Perlakuan varietas memberikan pengaruh terhadap tinggi tanaman, jumlah daun trifoliat bobot biji kering dan bobot 100 biji, perbedaan setiap varietas memiliki respon yang berbeda beda terhadap lingkungan tumbuh. Varietas kipas merah (V3) mampu beradaptasi baik dibandingkan dengan verietas anjasmoro (V2) dan baluran (V1) terhadap pertumbuhan tinggi tanaman, jumlah daun trifoliat umur 2, 4, 6 dan 8 MST, bobot biji kering dan 100 biji. Dosis kompos Azolla pinnata 60 g/polybag mampu meningkatkan pertumbuhan dan hasil tanaman.
\end{abstract}

Kata kunci : varietas, kedelai, pupuk organik 


\section{PENDAHULUAN}

Pertambahan jumlah penduduk mengakibatkan naiknya kebutuhan akan kedelai. Sementara itu produksi kedelai di Indonesia belum mampu mengimbangi kebutuhan sehingga pemerintah masih melakukan impor karena produksi dalam negeri hanya mampu memenuhi 30-40\% kebutuhan nasional (Puslitbangtan, 2012).

Badan Pusat Statistik (BPS) menyebutkan produksi kedelai nasional mengalami penigkatan yang cukup signifikan terjadi pada tahun 2014 sebesar 22,44\% menjadi 955,00 ribu ton, dari produksi tahun 2013 sebesar 779,99 ribu ton. Produksi kedelai tahun 2016 turun 7,85\% menjadi 887,54 ribu ton. Penurunan ini disebabkan oleh penurunan produksi kedelai di Pulau Jawa sebesar 12,55\% dan Luar Jawa sebesar 0,10\%.(BPS, 2016).

Rendahnya produksi kedelai Indonesia salah satunya dikarenakan belum maksimalnya pengetahuan petani dalam penggunaan teknologi produksi yang mendukung pertanian berkelanjutan dan semakin berkurangnya sumber daya lahan yang subur karena penggunaan pupuk anorganik secara terus menerus (Jumrawati, 2008). Untuk mengatasi permasalahan diatas diperlukan suatu usaha khusus untuk meningkatkan produksi tanaman kedelai. Beberapa upaya yang dapat dilakukan untuk peningkatan produksi yakni dengan penggunaan varietas unggul yang merupakan salah satu upaya yang mudah dan murah untuk meningkatkan produksi kedelai. Mudah karena teknologinya tidak rumit karena hanya mengganti varietas kedelai dengan varietas yang lebih unggul dan murah karena tidak memerlukan tambahan biaya produksi.

Keberadaan varietas mutlak diperlukan untuk meningkatkan kelestarian petani pada budidaya lokal. Pemerintah melalui departemen pertanian telah melepaskan berbagai varietas unggul. Pada tahun 1998 Balai Penelitian Kacang-kacangan dan Umbiumbian (BALITKABI) malang telah melepas sepuluh varietas unggul dengan ciri-ciri biji besar dan kandungan protein mencapai 42 persen. Bibit varietas yang sudah dilepas adalah

Barangrang,

baluran, Bromo,merubetiri, dan mahameru (Widianto, 2008). Menurut Arifin (2013) faktor lain pemicu rendahnya produksi kedelai yakni kurang tersedianya hara mineral pada tahap awal pertumbuhan khususnya kandungan hara mineral nitrogen. Mengingat pada tahap awal pertumbuhan bintil akar tanaman kedelai belum terbentuk sehingga belum mampu memfiksasi hara nitrogen, oleh sebab itu diperlukan tambahan asupan hara mineral $\mathrm{N}$ pada media tanam agar langsung dapat diserap oleh tanaman kedelai untuk digunakan dalam proses pertumbuhan dan perkembangannya.

Menurut Pasaribu (2009) bahwa pupuk yang layak digunakan harus memiliki pertumbuhan dan perkembangbiakan yang cepat, mempunyai kandungan unsur hara nitrogen yang cukup tinggi, cepat dan mudah terdekomposisi, mempunyai perbandingan $\mathrm{C} / \mathrm{N}$ ratio tanah yaitu 10-12, kemampuan menyerap air yang lebih besar serta tidak mengandung logam berat. Salah satu jenis tanaman yang memenuhi syarat tersebut adalah Azolla pinnata.

Azolla adalah tanaman pakis air yang berbentuk segitiga atau polygonal, tumbuh mengapung serta mengambang di permukaan air kolam, selokan dan sawah pada daerah beriklim tropis dan sub tropis ( Hidayat, Fanindi, Sopiyan dan Komarudin., 2011). Seperti halnya tanaman leguminosae, Azolla mampu menambat $\mathrm{N}_{2}$ udara karena berasosiasi dengan Sianobakteri (Anabaena azollae) yang hidup di dalam rongga daun Azolla.

Tanaman ini layak digunakan sebagai bahan organik karena memeliki kandungan nutrisi yang tinggi. Kompos Azolla pinnata memiliki nilai $\mathrm{C} / \mathrm{N}$ ratio rendah yaitu 10,4 sehingga mudah dan cepat termineralisasi haranya. Ketika proses mineralisasi berjalan lancar maka pemenuhan unsur hara $\mathrm{N}$ pada tanaman akan terpenuhi (Putra, Soenaryo dan Tyasmoro, 2013). Berdasarkan uraian diatas, Penelitian ini bertujuan untuk mengetahui respon pertumbuhan dan hasil berbagai varietas kedelai terhadap pemberian pupuk kompos Azolla pinnata. 


\section{BAHAN DAN METODE}

Bahan yang digunakan dalam penelitian ini adalah benih kedelai varietas Baluran, Anjasmoro, Kipas Merah, kompos Azolla pinnata, pupuk majemuk Phonska dan Polybag. Metode Penelitian menggunakan rancangan acak kelompok (RAK) pola faktorial. Terdiri dari dua faktor yaitu Faktor pertama adalah jenis varietas, yaitu $: \mathrm{V}_{1}=$ Baluran, $V_{2}=$ Anjasmoro dan $V_{3}=$ Kipas Merah. Faktor kedua adalah perlakuan kompos Azolla pinnata, yaitu : $\mathrm{A}_{0}=0$ $\mathrm{g} /$ polybag, $\mathrm{A}_{1}=20 \mathrm{~g} /$ polybag, $\mathrm{A}_{2}=40$ $\mathrm{g} /$ polybag dan $\mathrm{A}_{3}=60 \mathrm{~g} /$ polybag sehingga terdiri dari 12 kombinasi percobaan, masingmasing percobaan terdiri dari 3 ulangan.

\section{HASIL DAN PEMBAHASAN}

\section{Tinggi Tanaman}

Rata - rata tinggi tanaman pada penggunaan beberapa varietas kedelai dan pemberian Azolla pinata disajikan pada Tabel 1.

Tabel 1 perlakuan penggunaan tiga varietas kedelai memperlihatkan bahwa varietas terbaik dijumpai pada varietas kipas merah $\left(\mathrm{V}_{3}\right)$ pada umur 2, 4, 6 dan 8 MST yaitu
(21.55, 44.28, 72.03, 95.04) dibandingkan dengan varietas lainnya sedangkan penggunaan dosis pupuk kompos Azolla pinata terbaik dijumpai pada dosis $\mathrm{A}_{3}(60 \mathrm{~g} / \mathrm{polybag})$ yang mengakibatkan pertumbuhan tanaman semakin baik.

Perlakuan varietas memberikan pengaruh terhadap tinggi tanaman, jumlah daun trifoliat bobot biji kering dan bobot 100 biji, perbedaan setiap varietas memiliki respon yang berbeda beda terhadap lingkungan tumbuh. Hal ini sesuai dengan pernyataan Darliah (2001) pada umumnya suatu daerah memiliki kondisi lingkungan yang berbeda terhadap genotif. Respon genotif terhadap faktor lingkungan ini biasanya terlihat dalam penampilan fenotip dari tanaman dan salah satunya dapat dilihat dari pertumbuhan.

Kedelai varietas kipas merah merupakan varietas varietas lokal yang telah lama berkembang di Provinsi Aceh, khususnya di Kabupaten Biruen. Pada tahun 2008 telah terdaftar menjadi salah satu varietas unggul nasional (BPTP Aceh 2017). Sehingga memberikan respon yang sangat baik terhadap semua parameter sebagaimana hasil penelitian Kisman et al. (2007) menunjukkan bahwa setiap varietas memeliki respon yang berbeda terhadap pemberian pupuk.

Tabel 1. Rata- rata Tinggi Tanaman Kedelai pada Perlakuan Penggunaan Beberapa Varietas Kedelai Akibat Pemberian Kompos Azolla pinata

\begin{tabular}{lcccc}
\hline \multirow{2}{*}{ Perlakuan } & \multicolumn{4}{c}{ Tinggi Tanaman $(\mathrm{cm})$} \\
\cline { 2 - 5 } & $2 \mathrm{MST}$ & $4 \mathrm{MST}$ & $6 \mathrm{MST}$ & $8 \mathrm{MST}$ \\
\hline Varietas $(\mathrm{V})$ & & & $57.99 \mathrm{c}$ & $80.52 \mathrm{~b}$ \\
\hline $\mathrm{V}_{1}=$ Baluran & $19.16 \mathrm{~b}$ & $37.7 \mathrm{~b}$ & $66.52 \mathrm{~b}$ & $86.49 \mathrm{~b}$ \\
$\mathrm{~V}_{2}=$ Anjasmoro & $19.29 \mathrm{~b}$ & $42.57 \mathrm{a}$ & $72.03 \mathrm{a}$ & $95.04 \mathrm{a}$ \\
$\mathrm{V}_{3}=$ kipas merah & $21.55 \mathrm{a}$ & $44.28 \mathrm{a}$ & & \\
\hline Kompos Azola pinnata $(\mathrm{A})$ & & & $59.47 \mathrm{c}$ & $78.99 \mathrm{c}$ \\
$\mathrm{A}_{0}(0)$ & $17.95 \mathrm{c}$ & $36.74 \mathrm{c}$ & $62.97 \mathrm{bc}$ & $85.09 \mathrm{bc}$ \\
$\mathrm{A}_{1}(20 \mathrm{~g})$ & $19.46 \mathrm{~b}$ & $40.7 \mathrm{~b}$ & $65.92 \mathrm{~b}$ & $89.26 \mathrm{ab}$ \\
$\mathrm{A}_{2}(40 \mathrm{~g})$ & $20.51 \mathrm{~b}$ & $42.0 \mathrm{~b}$ & $73.70 \mathrm{a}$ & $96.07 \mathrm{a}$ \\
$\mathrm{A}_{3}(60 \mathrm{~g})$ & $22.09 \mathrm{a}$ & $46.6 \mathrm{a}$ & $\mathrm{c}$ & \\
\hline
\end{tabular}

Ket: Angka angka yang diikuti oleh huruf yang sama pada kolom yang sama tidak berbeda nyataberdasarakan uji duncan pada taraf 0.05 


\section{Jumlah Daun Trifoliate (Helai)}

Berdasarkan Tabel 2 dapat diketahui bahwa perlakuan penggunaan tiga varietas kedelai pada umur 6 MST dan 8 MST memberikan pengaruh yang sangat nyata pada varietas kipas merah $\left(\mathrm{V}_{3}\right)$ dengan nilai tertinggi (12.04 dan 29.05) sedangkan perlakuan dosis kompos azolla pinnata pada umur 2, 4, 6 dan 8 MST terbaik dijumpai pada dosis $\left(\mathrm{A}_{3}\right) \quad 60 \mathrm{~g} /$ polybag dengan rataan tertinggi $(2.37,5.43,12.84$ dan 30.25).

Setiap varietas tanaman kedelai mempunyai karakter atau faktor genetik yang berbeda beda anatara varietas satu dengan varietas lainnya.Hal ini sesuai dengan pernyataan Gabesius et.al. (2012) yang menyatakan bahwa perbedaan susunan genetik merupakan salah satu faktor penyebab keragaman penampilan tanaman. Hasil penelitian ini juga sejalan dengan dengan pendapat Sitompul dan Guritno (1995) yang menyatakan bahwa jenis varietas berpengaruh sangat nyata pada tinggi tanaman hal ini disebabkan adanya perbedaan genetik yang terdapat pda masing masing tanaman
Diperkuat Ratnasari et al. (2015) yang menyatakan bahwa produktivitas kedelai dapat ditingkatkan dengan perbaikan teknik budidaya melalui penggunaan varietas ungggul, masing masing varietas akan memeberikan respon pertumbuhan dan tingkat produksi yang berbeda-beda. Setiap varietas mempunyai sifat genetik yang tidak sama sehingga perbedaan sifat genetik tersebut dapat menunjukan respon yang berbeda terhadap lingkungaan dan faktor produksi.

Perlakuan penggunaan kompos Azolla pinnata dosis $60 \mathrm{~g} /$ polybag menghasilkan rataan tertinggi pada semua parameter . Hal ini dikarenkan unsur hara nitrogen yang terkandung pada kompos Azolla pinnata digunakan sebagai bahan fotosintesis untuk membentuk fotosintat yang akan berperan pada laju pertumbuhan vegetatif seperti tinggi tanaman dan jumlah daun.semakin tinggi suatu tanaman maka semakin banyak pula jumlah daun yang dihasilkan,sedangkan semakin banyak jumlah daun yang dihasilkan maka akan berbanding lurus dengan peningkatan jumlah polong.

Tabel 2. Rata- rata Jumlah Daun Trifoliate (Helai)Kedelai pada Perlakuan Penggunaan Beberapa Varietas Kedelai Akibat Pemberian Kompos Azolla pinata

\begin{tabular}{lcccc}
\hline \multirow{2}{*}{ Perlakuan } & \multicolumn{4}{c}{ Jumlah Daun Trifoliate (Helai) } \\
\cline { 2 - 5 } & $2 \mathrm{MST}$ & $4 \mathrm{MST}$ & $6 \mathrm{MST}$ & $8 \mathrm{MST}$ \\
\hline Varietas (V) & 1.88 & 4.46 & $9.60 \mathrm{~b}$ & $24.13 \mathrm{~b}$ \\
\hline $\mathrm{V}_{1}=$ Baluran & 2.08 & 4.59 & $11.95 \mathrm{a}$ & $26.90 \mathrm{a}$ \\
$\mathrm{V}_{2}=$ Anjasmoro & 2.12 & 4.73 & $12.04 \mathrm{a}$ & $29.05 \mathrm{a}$ \\
$\mathrm{V}_{3}=$ kipas merah & & & & \\
\hline Kompos Azola pinnata (A) & $1.72 \mathrm{c}$ & $3.87 \mathrm{c}$ & $9.240 \mathrm{~b}$ & $22.10 \mathrm{c}$ \\
\hline $\mathrm{A}_{0}$ (0 gr) & $1.87 \mathrm{bc}$ & $4.28 \mathrm{bc}$ & $10.31 \mathrm{~b}$ & $24.96 \mathrm{~b}$ \\
$\mathrm{~A}_{1}$ (20 gr) & $2.15 \mathrm{ab}$ & $4.80 \mathrm{ab}$ & $12.40 \mathrm{a}$ & $29.46 \mathrm{a}$ \\
$\mathrm{A}_{2}$ (40 gr) & $2.37 \mathrm{a}$ & $5.43 \mathrm{a}$ & $12.84 \mathrm{a}$ & $30.25 \mathrm{a}$ \\
$\mathrm{A}_{3}$ (60 gr) &
\end{tabular}

Ket: Angka angka yang diikuti oleh huruf yang sama pada kolom yang sama tidakberbeda nyata berdasarkan uji duncan pada taraf 0.05 


\section{Bobot Biji Kering Pertanaman (g) dan Berat 100 Biji (g)}

Berdasarkan Tabel 3 perlakuan penggunaan tiga varietas kedelai memperlihatkan bahwa varietas terbaik pada bobot biji kering dan berat 100 biji dijumpai pada varietas (V3) kipas merah yaitu 17.58 dan 10.39 sedangkan terendah terdapat pada varietas (V1) baluran dengan hasil 11.34 dan 6.76. Untuk perlakuan pupuk kompos Azolla pinnata pada bobot biji kering dan berat 100 biji terbaik dijumpai pada (A3) dosis 60 $\mathrm{g} /$ polybag dengan nilai tertinggi yaitu 17.23 dan 9.27 sedangkan terendah dijumpai pada dosis 0 gr/polybag $\left(\mathrm{A}_{0}\right)$ dengan nilai 12.03 dan 8.42 .

Suhartono et al. (2008) menyatakan bahwa ketersedian unsur hara dipenuhi oleh adanya kompos, akan mampu memberikan tunjangan kehidupan bagi pertumbuhan dan perkembangan tanaman kedelai yang baik. Pemberian kompos Azolla pinnata memberikan kontribusi terhadap tinggi tanaman kedelai. Gunawan dan Kartini (2012), menjelaskan bahwa pupuk organik Azolla pinnata mengandung banyak sumber hara nitrogen sehingga semakin tinggi dosis pupuk nitrogen yang diberikan, semakin bertambah pula tinggi tanaman.

Menurut Zainal, et al., (2014), semakin baik pertumbuhan vegetatif tanaman kedelai maka proses fotosintesis akan berjalan dengan baik sehingga fotosintat yang dihasilkan mampu meningkatkan berat biji. Nurlisan et al. (2013),memaparkan, bahwa unsur Nitrogen yang terdapat dalam kompos Azolla setelah diserap oleh tanamn merupakan penyusun bahan organik baik didaun maupun didalam biji sehingga pemberian pupuk yang mengandung $\mathrm{N}$ pada tanaman akan meningkatkan bobot 100 biji.

Menurut Sutanto (2002) Hasil dekomposisi Azolla pinnata akan memasok N lebih cepat sehingga berperan dalam meningkatkan jumlah daun karena unsur hara $\mathrm{N}$ yang berperan dalam pertumbuhan vegetatif tanaman untuk membentuk protein dalam klorofil yang digunakan untuk proses fotosintesis. Pada Tabel analis ragam menunjukkan bahwa pada penggunaan pupuk kompos azolla pinnata memberikan pengaruh yang nyata terhadap jumlah cabang produktif Hal ini dikarenakan ketika memasuki tahap generatif tanaman kedelai memerlukan serapan hara mineral yang jauh lebih tinggi terlebih unsur hara nitrogen untuk proses perkembangan jaringan . Menurut wibowo (2010) semakin tinggi kompos Azolla yang diberikan maka hasil yang diperoleh semakin meningkat yang mana sebagian besar asimilat digunakan organ generatif untuk pembentukan polong.

Menurut Zainal, et al. (2014), semakin baik pertumbuhan vegetatif tanaman kedelai maka proses fotosintesis akan berjalan dengan baik sehingga fotosintat yang dihasilkan mampu meningkatkan berat biji. Nurlisan, et al., (2013),memaparkan, bahwa unsur Nitrogen yang terdapat dalam kompos Azolla setelah diserap oleh tanamn merupakan penyusun bahan organik baik didaun maupun didalam biji sehingga pemberian pemberian pupuk yang mengandung $\mathrm{N}$ pada tanaman akan meningkatkan bobot 100 biji.

Sutiarto dan Widawati (2016) bahwa kompos Azolla pinnata mampu menyediakan unsur hara makro dan mikro untuk meningkatkan produktifitas tanaman serta dapat memperbaiki struktur tanah dengan kandungan bahan organik, sejalan dengan Prihatman (2000) yang menyatakan bahwa bahwa kedelai dapat tumbuh baik pada berbagai jenis tanah, asal drainase dan aerasi tanah cukup baik. Pada tanah tanah pedsolik merah kuning pertumbuhan kedelai kurang baik, kecuali bila diberi tambahan pupuk organik atau kompos dalam jumlah yang cukup. 
Tabel 3. Rata- rata Bobot Biji Kering (g) dan Berat 100 Biji (g) Kedelai pada Perlakuan Penggunaan Beberapa Varietas Kedelai Akibat Pemberian Kompos Azolla pinata

\begin{tabular}{lcc}
\hline \multicolumn{1}{c}{ Perlakuan } & Bobot Biji Kering $(\mathrm{g})$ & Berat 100 Biji $(\mathrm{g})$ \\
\hline Varietas $(\mathrm{V})$ & & \\
\hline $\mathrm{V}_{1}=$ Baluran & $11.34 \mathrm{c}$ & $6.76 \mathrm{c}$ \\
$\mathrm{V}_{2}=$ Anjasmoro & $14.72 \mathrm{~b}$ & $9.63 \mathrm{~b}$ \\
$\mathrm{~V}_{3}=$ kipas & $17.58 \mathrm{a}$ & $10.39 \mathrm{a}$ \\
merah & & \\
\hline Kompos Azola pinnata $(\mathrm{A})$ & $12.03 \mathrm{c}$ & $8.42 \mathrm{~b}$ \\
$\mathrm{~A}_{0}(0 \mathrm{~g})$ & $13.56 \mathrm{c}$ & $9.04 \mathrm{ab}$ \\
$\mathrm{A}_{1}(20 \mathrm{~g})$ & $15.37 \mathrm{~b}$ & $9.26 \mathrm{a}$ \\
$\mathrm{A}_{2}(40 \mathrm{~g})$ & $17.23 \mathrm{a}$ & $9.27 \mathrm{a}$ \\
$\mathrm{A}_{3}(60 \mathrm{~g})$ & & \\
\hline
\end{tabular}

Ket: Angka angka yang diikuti oleh huruf yang sama pada kolom yang sama tidak berbeda nyata berdasarakan uji duncan pada taraf 0.05

\section{SIMPULAN}

Varietas kipas merah (V3) mampu beradaptasi baik dibandingkan dengan verietas anjasmoro (V2) dan baluran (V1) terhadap pertumbuhan tinggi tanaman, jumlah daun trifoliat umur 2, 4, 6 dan 8 MST, bobot biji kering dan 100 biji. Dosis kompos Azolla pinnata $60 \mathrm{~g} /$ polybag mampu meningkatkan pertumbuhan dan hasil tanaman.

\section{DAFTAR PUSTKA}

Arifin 2013., Kajian Morfologi Anatomi dan Agronomi antara kedelai sehat dan kedelai Terserang Cowpea mild Mottle Virus, Jurnal bahan Ajar Sekolah Kejuruan. 1(3). 110-120

BPTP Aceh, 2017. Balai besar pengkajian dan Pengembangan Teknolgi Pertanian Kementrian Pertanian.

BPS, 2016. Outlook Komoditas Pertanian Sub

Sektor Tanaman Pangan. Kementrian Pertanian

Gabesius, Y.O. Siregar, L.A.M. dan Husni. Y. 2012. Respon pertumbuhan dan produksi beberapa varietas kedelai terhadap pemberian pupuk bokashi.
Jurnal Online Agroekoteknologi 1 (1) : 220-236.

Hidayat, C. Fanindi, A. Sopiyana, s dan Komarudin. 2011.Peluang

Pemanfaatan Tepung Azolla Sebagai Bahan Pakan Sumber Protein Untuk Ternak Ayam. Bogor: Seminar Nasional Teknologi Peternakan danVeteriner.

Jumrawati, 2008. Efecktifitas Inokulasi Rhizobium sp. Terhadap Pertumbuhan dan Hasil Kedelai pada Tanah Jenuh Air. LIPI Press. Jakarta

Kisman,N.Khumaida, Tri koessoe maningtyas, Sobir, D.Sopandie. 2007. Karakter morfo-fi siologi daun, penciri adaptasi kedelai terhadap intensitas cahaya rendah pada Kondisi Terbuka dan Ternaungi. Buletin Agronomi 33: 2432.

Nurlisan, Rasyad, A dan Yoseva, S. 2013. Pengaruh Pemberian Pupuk Organik Terhadap Pertumbuhan dan Hasil Tanaman Kedelai. Jurnal Agroteknologi Fakultas Pertanian Universitas Riau.

Pasaribu, E.A. 2009. Pengaruh Waktu Aplikasi dan Pemberian Berbagai Dosis Kompos Azolla (Azolloa sp) terhadap 
Pertumbuhan dan Produksi Tanaman Kailan (Brassica oleracea Var. Achephala DC). Skripsi. Medan: Departemen Budidaya Pertanian Fakultas Pertanian Univeritas Sumatra Utara

Pertumbuhan Dan Hasil Tanaman Kedelai (Glycine $\max$ (L.) Merill) Pada Berbagai Jenis Tanah. (online) (http://pertanian. trunojoyo.ac.id/wpcontent/ upload/2012/03/09suhartono.pdf diakses 21/10/2013: 14:21 WIB).

Prihatman, 2000. Kedelai (Glycine max L.). Dikutip dari http://www.ristek.go.id. Diakses pada tanggal 3 November 2009.

Putra DF, Soenaryo, Tyasmoro SY. 2013. Pengaruh pemberian berbagai bentuk Azolla dan pupuk N terhadap pertumbuhan dan hasil tanaman jagung manis (Zea mays var Saccharata). Jurnal

Produksi Tanaman 1(4): 353-360.

Pusat Penelitian dan Pengambangan tanaman Pangan, 2012. Pengembangan Teknologi Kedelai di

Beberapa Daerah. Berita puslitbangtan. No.51 Januari 2018

Ratnasari, D., M.K. Bangun dan R.I. M. Damanik. 2015. Respons Dua dua Varietas varietas Kedelai kedelai (Glycine $\max$ L. Merill.) pada Pemberian pemberian Pupuk pupuk Hayati hayati dan NPK Majemuk.
Jurnal Online Agroekoteknologi (3) 1:276-282. Desember 2015.

ISSN No 2337-6597.

Setiarto, R.H.B. dan N. Widhyastuti. 2016. Penurunan kadar tanin dan asam fitat pada tepung sorgum melalui fermentasi Rhizopus oligosporus, Lactobacillus plantarum dan Saccharomyces cerevisiae. Berita Biologi. 15 (2): 149157.

Sitompul, S. M. dan Guritno, B. 1995. Analisis Pertumbuhan Tanaman. UGM Press: Yogjakarta

Suhartono, Zaed, R.A.S., dan Khoiruddin, A. 2008. Pengaruh Interval Pemberian Air Terhadap Zainal, M., A.Nugroho, dan N. E. Suminarti. 2014. Respon pertumbuhan dan hasil tanaman kedelai (Glycine max (L) Merill) pada berbagai tingkat pemupukan $\mathrm{N}$ dan pupuk

kandang ayam. J. Produksi Tanaman 2 (6) :484-490

Sutanto, R. 2002. Pertanian Organik. Kanisius Jakarta

Wibowo, A. 2010. Pengaruh Waktu Aplikasi dan Pemberian Berbagai Dosis Kompos Azolla terhadap Pertumbuhan dan Produksi Tanaman Kedelai (Glycine $\max$ (L) Merrill). Skripsi. Medan: Universitas Sumatera Utara

Widianto, H. 2010. Protein Kedelai dan Kecambah Manfaatnya Bagi Kesehatan. Yogyakarta (ID); Kanisius. 